\title{
PENGARUH BULETIN FISIKA BERBENTUK BUKU SAKU UNTUK MENINGKATKAN HASIL BELAJAR SISWA DI MAN 2 BIMA KELAS X MATERI HUKUM NEWTON TAHUN PELAJARAN 2018/2019
}

\author{
Abdul Mikraj ${ }^{1 *}$, Linda Sekar Utami², Zulkarnain ${ }^{3}$ \\ ${ }^{1 *}$ Mahasiswa Sarjana Program Studi Pendidikan Fisika Universitas Muhammadiyah Mataram \\ ${ }^{283}$ Dosen Progran Studi Pendidikan Fisika Universitas Muhammadiyah Mataram \\ ${ }^{*}$ Corresponding author : \\ Email: lindasekarutami@gmail.com
}

Diterima 9 Mei 2019, Disetujui 15 Mei 2019

\begin{abstract}
ABSTRAK
Tujuan dari penelitian ini untuk mengetahui pengaruh Buletin Fisika Berbentuk Buku Saku terhadap peningkatkan hasil belajar siswa kelas X MAN 2 BIMA pada hukum newton tahun pelajaran 2018/2019. Penelitian ini merupakan penelitian jenis quasi experiment researcha dengan metode control grup design subjek dalam penelitian ini adalah seluruh siswa Kelas X MAN 2 BIMA.Sampel dalam penelitian di ambil secara purposive sampling dengan kelas $\mathrm{X}_{\mathrm{A}}$ sebagai kelasd eksperimen yang berjumlah 28 orang siswa dan kelas $X_{B}$ sebagai kelas kontrol yang berjumlah 28 orang siswa.Instrumen yang di gunakan berupa tes yang telah di uji kelayakanya. hal ini bisa di lihat dari rata-rata kelas experiment pre-test yaitu 61 dan post-test yaitu 82,sedangkan kelas kontrol hasil belajar nilai rata-rata pre-test yaitu 61 dan post-test yaitu 73.Berdasarkan hasil perhitungan uji hipotesis dengan menggunkan rumus uji-tes, maka diperoleh $t_{\text {hitung }}$

sebesar 3,630 sedangkan nilai $t_{\text {tabel }}$ pada taraf signifikan $5 \%$ dengan $\mathrm{dk}=n_{1}+n_{2}-2=28+28-2=54$ diperoleh harga $t_{\text {tabel }}$ sebesar 2,175. Jadi dari hasil perhitungan dapat disimpulkan $t_{\text {hitumg }}>t_{\text {tabel }}$, maka dapat dikatakan hipotesis (Ha) diterima.sehingga dapat di ambil kesimpulan bahwa terdapat pengaruh yang signifikan terhadap hasil belajar fisika siswa menggunakan buletin fisika berbentuk buku saku materi hukum newton pada siswa kelas X di MAN 2 BIMA tahun pelajaran 2018/2019
\end{abstract}

Kata Kunci: Buletin Fisika, Buku Saku, dan hasil Belajar siswa

\section{PENDAHULUAN \\ Latar Belakang}

Pembelajaran pada hakekatnya adalah proses komunikasi, yaitu proses penyampaian pesan dari guru melalui saluran atau media tertentu ke penerima pesan. Pesan yang akan dikomunikasikan adalah materi ataupun konsepkonsep yang ada dalam kurikulum. Keberhasilan dalam proses mengajar yang disampaikan oleh seorang guru dalam belajar di kelas dipengaruhi oleh banyak faktor antara lain guru, siswa, lingkungan belajar, kurikulum, sumber belajar dan lain-lain. Guru dan siswa merupakan faktor yang paling penting dalam proses pembelajaran. Kegiatan pembelajaran merupakan suatu proses yang tidak lepas dari komponen-komponen lain yang saling berinteraksi didalamnya. Tujuannya adalah untuk menarik perhatian siswa terhadap suatu materi yang disampaikan oleh seorang guru.Tentunya dengan selalu memberikan inovasi-inovasi yang dapat menarik perhatian dan semangat belajar dari seorang siswa.Selain itu dikalangan siswa telah berkembang kesan yang kuat bahwa pelajaran fisika merupakan pelajaran yang sulit untuk dipahami dan kurang menarik, hal ini diakibatkan kurang minat dan motivasi untuk mempelajari fisika dengan senang hati, banyak siswa untuk terpaksa belajar fisika (Hartati, 2010: 128).Sehingga sebagian guru mungkin menganggap kegiatan pembelajaran semakin hari mengalami kemunduran. Sehingga mengakibatkan belajar menjadi kegiatan yang membosankan, statis, siswa menjadi malas, mengantuk, berbuat aneh-aneh. Hal tersebut juga diakibatkan karena cara mengajar dan media pembelajaran yang digunakan oleh guru kurang mampu untuk meningkatkan hasil belajar siswa. Berbagai cara dapat ditempuh oleh guru agar pembelajaran menarik, kontekstual, tidak membosankan, mudah dipahami sehingga pengalaman belajar yang dialami oleh siswa lebih menyenangkan.

Upaya menciptakan peran aktif siswa dalam kegiatan pembelajaran perlu dilakukan agar pembelajaran tidak terfokus pada satu sumber saja, yaitu guru. Oleh karena itu dengan 
upaya peran aktif siswa, maka akan timbul pula proses pembelajaran antar siswa itu sendiri. Dan salah satu pertanda seorang siswa telah belajar adalah adanya perubahan tingkah laku pada diri siswa itu yang bisa disebakan oleh terjadinya perubahan pada tingkat pengetahuan, keterampilan, atau sikapnya.

Pengetahuan dan keterampilan seorang siswa harus selalu dikembangkan, khususnya untuk mata pelajaran yang memerlukan tingkat analisis yang tinggi seperti Fisika.Fisika merupakan ilmu pengetahuan yang paling mendasar karena berhubungan dengan perilaku dan struktur benda.Salah satu hal penting yang perlu diperhatikan dalam mendukung pembelajaran fisika sehingga penyampaian konsep dapat lebih baik yaitu tersedianya sarana yang salah satunya berupa media pembelajaran.

Masalah yang sering terjadi disekolah yaitu metode pengajaran yang digunakan oleh guru yang bertindak sebagai sumber utama dan siswa adalah pendengar dalam proses pembelajaran serta kurang maksimalnya penggunaan media dan teknologi dalam proses pembelajaran. Pada umumnya penggunaan media pembelajaran sangat membantu guru mengembangkan dan memperdalam proses belajar mengajar di kelas. Penggunaan media pembelajaran yang bervariasi dengan tepat dapat mempengaruhi aktivitas, minat dan motivasi belajar siswa yangtentunya akan mempengaruhi hasil belajarnya.

Salah satu media pembelajaran yang dapat digunakan dalam mata pelajaran Fisika adalah Buletin Fisika berbentuk buku saku. Buletin Fisika berbentuk buku saku adalah media cetak berisi warta singkat atau materi fisika tertulis yang diterbitkan secara periodik dalam bentuk buku saku, sehingga sangat mudah dibawa. Buletin Fisika berfungsi sebagai alat komunikasi pendidik yang dapat menginformasikan ilmu dan pengetahuan sebagai alat memperlancar komunikasi pembelajaran.Sehingga siswa lebih termotivasi dalam belajar karena buletin yang dikembangkan menampilkan gambar, materi serta warna yang menarik disetiap edisinya.

$\mathrm{Hal}$ ini sesuai dengan penelitian yang dilakukan oleh Dewi, dkk (2016) tentang pengembangan media pembelajaran fisika berupa buletin dalam bentuk buku saku didapatkan hasil bahwa terjadi peningkatan hasil rata-rata minat baca sebesar $11,13 \%$. Hal ini mempermudah siswa untuk memahami materi mata pelajaran fisika.

Pentingnya penggunaan media pembelajaran berupa buletin fisika berbentuk buku saku ditunjukkan oleh cara mengajar guru di MAN 2 Bima kelas $X$ yang masih kurang menggunakan media pembelajaran yang bervariasi sehingga membuat siswa merasa bosan dan minimnya hasil belajar siswa. Sehingga yang terjadi siswa lebih senang berbicara dan melakukan aktivitas lain dari pada mendengar penjelasan guru.

Berdasarkan uraian di atas, maka peneliti tertarik untuk melakukan penelitian eksperimenyang berjudul "Pengaruh Buletin Fisika Berbentuk Buku Saku Untuk Meningkatkan Hasil Belajar Siswa MAN 2 Bima Kelas X Pada Materi Hukum Newton Tahun Pelajaran 2018/2019" dengan harapan siswa dapat lebih aktif dalam proses pembelajaran serta dapat menguasai konsep-konsep materi fisika dengan baik melalui pengembangan pembelajaran Buletin Berbentuk Buku Saku.

\section{METODE PENELITIAN \\ Rancangan Penelitian}

Berdasarkan pada permasalahan yang diteliti, metode yang digunaakan dalam penelitian ini adalah penelitian Quasi experiment reseerdengan pendekatan kuantitatif. Menurut Sugiyono (2012 : 75) bahwa "metode penelitian control group design" sampel yang digunakan untuk eksperimen maupun sebagai kelompok kontrol diambil secara random dari populasi tertentu. Jadi cirinya adalah adanya kelompok kontrol dan sampel dipilih secara random.

Metode penelitian kuantitatif yang dijelaskan oleh Sugiyono (2015:14) adalah metode penelitian sebagai metode yang berlandaskan pada filsafat positivisme, metode yang digunakan untuk meneliti pada populasi atau sampel tertentu, teknik pengambilan sampel biasanya dilakukan dengan perhitungan teknik sampel tertentu yang sesuai, pengumpulan data merupakan instrument penelitian, analisis data bersifat kuantitatif/statistik dengan tujuan untuk menguji hipotesis yang telah ditetapkan.

Penelitian ini termasuk jenis penelitian eksperimen yang terdiri dari pemberian tes awal (pre-test) maupun tes akhir (post-test) baik kepada kelompok eksperimen maupun kelompok kontrol dengan rancangan penelitian sebagai berikut :

Table. Metode pretest-Posttest Control Group Desaign

\begin{tabular}{|l|c|c|c|}
\hline \multicolumn{1}{|c|}{ Kelas } & Pretest & Treatment & Posttest \\
\hline $\begin{array}{l}\text { Kelas } \\
\text { eksperimen }\end{array}$ & O1 & $X$ & O2 \\
\hline Kelas control & O3 & - & 04 \\
\hline
\end{tabular}

Keterangan :

$\mathrm{R}$ : Kelompok eksperimen dan kontrol diambil secara random (acak).

01 : Pretest sebelum diberi perlakuan dengan media buletin fisika berbentuk buku saku. 
O3 : Pretest sebelum diberi perlakuan dengan metode ceramah.

O2: Posttest yang dikenakan setelah diberi perlakuan dengan buletin fisika berbentuk buku saku.

O4 : Posttest yang dikenakan setelah diberikan perlakuan metode ceramah.

$X$ : Treatment (perlakuan) terhadap kelompok eksperimen yaitu dengan menggunakan media buletin fisika berupa buku saku.

\section{Lokasi dan Waktu Penelitian}

1. Lokasi Penelitian

Penelitian ini dilaksakan diMAN 2 Bima kelas $\mathrm{X}$.

\section{Waktu Penelitian}

Penelitian ini dilaksanakan pada bulanAgustus 2018 pada Siswa MAN 2 Bima kelas X.

\section{Variabel Penelitian}

Menurut Sugiyono (2015:61) menjelaskan bahwa variabel penelitian adalah suatu atribut atau sifat atau nilai dari orang, obyek atau kegiatan yang mempunyai variabel tertentu yang ditetapkan oleh peneliti untuk dipelajari dan kemudian ditarik kesimpulannya. Jadi dalam penelitian ini hanya terdapat satu variabel (variabel tunggal) yaitu faktor yang mempengaruhi media Buletin Fisika berupa buku saku terhadap hasil belajar siswa MAN 2 Bima kelas X.

\section{Variabel Bebas}

Variabel Bebas atau juga dikenal dengan istilah variabel Independent adalah merupakan variabel yang diduga memiliki fungsi sebagai penyebab timbulnya variabel yang lain. Biasanya variabel bebas akan dimanipulasi, diamati dan diukur dengan tujuan untuk mengetahui sejauh mana pengaruhnya terhadap variabel lainnya. Secara singkat, variabel bebas adalah variabel yang dapat mempengaruhi atau menjadi penyebab perubahan atau timbulnya variabel dependen/terikat (Sugiyono, 2015:62). Jadi, variabel bebas adalah media Buletin Fisika berupa buku saku.

\section{Variabel Terikat}

Jenis variabel kedua adalah variabel terikat atau disebut juga dengan istilah dependent atau variable Output atau Kriteria atau Konsekuen. la adalah hasil / akibat yang ditimbulkan oleh variabel bebas. variabel ini merupakan hasil yang timbul sebagai akibat langsung dari manipulasi dan pengaruh variabel bebas. Dalam sebuah penelitian variabel tergantung diamati dan diukur untuk mengetahui pengaruh dari variabel bebas. Disini variabel dependen juga disebut dengan variabel terikat yaitu variabel yang dipengaruhi atau yang menjadi akibat, karena adanya variabel bebas. Variabel tergantung berfungsi untuk mengetahui pengaruh dari variabel bebas (sugiyono, 2015:62) Jadi, variabel terikat adalah hasil belajar siswa.

\section{Penentuan Subjek Penelitian}

1. Populasi

Menurut Arikunto, (2015:173) populasi adalah keseluruhan subjek penelitian. Apabila seseorang ingin meneliti semua elemen yang ada dalam wilayah penelitian, maka penelitiannya merupakan penelitian populasi. Dalam penelitian ini yang menjadi populasinya adalah kelas X MAN 2 Bima.

\section{Sampel}

Menurut Riduwan, (2014:70) mengatakan bahwa: "sampel adalah bagian dari populasi." Sampel penelitian adalah sebagaian dari populasi yang diambil sebagai sumbper data yang dapat mewakili seluruh populasi. Bila populasi besar, dan peneliti tidak mungkin mempelajari semua yang ada pada populasi, maka peneliti dapat menggunakan sampel yang ada pada populasi itu. Sehingga yang menjadi sampel di penelitian ini yaitu siswa kelas Xa dan Xb di MAN 2 Bima.

Jadi teknik yang digunakan dalam penelitian ini adalah purposive sampling. Dimana peneliti dalam memilih sampel dengan memberikan kesempatan yang sama kepada semua anggota populasi untuk ditetapkan sebagai anggota sampel. Dengan tehnik semacam ini maka terpilihnya individu menjadi anggota sampel benar-benar atas dasar faktor kesempatan (chance), dalam arti memiliki kesempatan yang sama, bukan karena adanya pertimbangan subjektif, dari peneliti. Teknik ini merupakan yang paling objektif, dibandingkan dengan teknik-teknik sampling yang lain. Simple random sampling merupakan pengambilan anggota sampel dari populasi yang dilakukan secara acak tanpa memperhatikan strata yang adadalam populasi itu.

\section{Teknik Pengumpulan Data}

Dalam Riduwan (Nasir, 2003:328) mengatakan bahwa teknik pengumpulan data merupakan alat ukur yang diperlukan dalam melaksanakan suatu penelitian. Terdapat beberapa metode dalam pengumpulan data penelitian, berikut ini terdapat cara untuk mengumpulkan berbagai informasi yang diperlukan peneliti, diantaranya adalah :

1. Tes

Tes berasal dari bahasa latin testum yang berarti alat untuk mengukur tanah. Dalam bahasa prancis kuno, kaata tes berarti ukuran yang dipergunakan untuk membedakan antara emas dengan perak serta logam lainnya (Toha, 2011:43 ). Testing adalah saat 
pengambilan tes, testee adalah responden yang sedang mengerjakan tes sedangkan tes,tester adalah subjek evaluasi (Arikunto, 2012:53).

Tes yang dibuat berupa pilihan ganda dengan jumlah 20 soal yang dilaksanakan sebelum dan sesudah diberikan. Tes bentuk pilihan ganda adalah sejenis tes kemampuan belajar yang memerlukan jawaban bersifat pilihan.

Soal yang digunakan pada tes awal sama dengan soal yang akan digunakan pada tes akhir. Hal ini dimaksudkan supaya tidak ada pengaruh perbedaan instrumen terhadap perubahan hasil belajar fisika yang terjadi.

Dari uraian diatas jika dikaitkan dengan evaluasi pendidikan dapat ditarik kesimpulannya bahwa materi yang digunakan adalah kelistrikan dan kemagnetan. Sehingga bisa mengetahui peningkatan hasil belajar dan motivasi belajar siswa.

\section{Instrumen Penelitian}

Menurut Sugiyono (2012:148) Instrumen penelitian merupakan suatu alat yang akan digunakan oleh peneliti dalam kegiatan mengumpulkan data agar kegiatan tersebut menjadi sistematis dan dipermudah dalam melakukan penelitian. Sedangkan menurut Riduwan (2010:71) Instrumen penelitian adalah seluruh alat pengambilan data yang digunakan dalam penelitian yang mencakup proses pengumpulan data dan teknik penentuan kualitas (validitas dan reabilitas instrument penelitian).

Instrumen penelitian yang digunakan dalam penelitian ini adalah tes berupa pilihan ganda, Tes pilihan ganda merupakan bentuk tes yang butir-butir soalnya selalu terdiri atas dua komponen utama yaitu system yang menghadapkan siswa kepada sebuah pertanyaan tak lengkap atau satu pertanyaan langsung; dan dua atau lebih pilihan jawaban yang mana satu diantaranya lebih benar dan sisanya salah (Ekoputro, 2012:61).

\section{Uji Coba Instrumen Peneliti}

1. Uji Coba Instrumen Tes

Sebagai acuan kevaliditasan dan kelreabilitasan soal, digunakan formula uji kevaliditas dan reliabilitas.

\section{a. Uji Validitas}

Menurut Riduwan

(2014:73) menjelaskan bahwa Validitas adalah suatu ukuran yang menunjukkan tingkat keandalan atau kesahihan suatu alat ukur. Alat ukur yang kurang valid berarti memiliki validitas rendah. Untuk menguji validitas alat ukur, terlebih dahulu dicari harga korelasi antara bagian-bagian dari alat ukur secara keseluruhan dengan cara mengkorelasikan setiap butir alat ukur dengan skor total yang merupakan jumlah tiap skor butir. Untuk menghitung validitas digunakan rumus pearson product moment adalah.

$r_{x y}=\frac{N \sum X Y-\left(\sum X\right)\left(\sum Y\right)}{\sqrt{\left\{N \sum X^{2}-\left(\sum X\right)^{2}\right\}\left\{N \sum Y^{2}-\left(\sum Y\right)^{2}\right\}}}$

Keterangan :

$r_{x y}=$ Koefisien korelasi antara $\mathrm{x}$ dan $\mathrm{y}$

$\mathrm{N}=$ Jumlah siswa

$\Sigma X=$ Skor tiap butir soal

$\Sigma Y=$ Jumlah skor total

$\Sigma$ X2 = Jumlah kuadrat skor tiap butir soal

$\Sigma Y 2=$ Jumlah kuadrat skor total

$(\Sigma X) 2=$ Kuadrat jumlah skor semua butir

soal

$(\Sigma Y) 2=$ =Kuadrat jumlah skor total

Hasil perhitungan dikonsultasikan dengan harga Product Moment pada tabel dengan taraf signifikan 5\%. Jika $r_{x y}>r_{\text {tabel }}$ maka item soal tersebut dikatakan valid (Arikunto, 2010: 213).

b. Uji Reliabilitas Instrumen

Reliabilitas berhubungan dengan masalah kepercayaan atau keterandalan. Menurut Arikunto (2010: 221), suatu tes dikatakan mempunyai taraf kepercayaan yang tinggi (reliabel) jika tes tersebut dapat memberikan hasil yang tetap. Terdapat beberapa teknik yang dapat digunakan untuk menguji reliabilitas instrumen, salah satunya dengan menggunakan rumus K-R.20 dengan rumus sebagai berikut:

$$
\begin{array}{r}
\mathrm{r}_{11}=\left(\frac{n}{n-1}\right)\left(\frac{S_{t}{ }^{2}-\sum p_{i} q_{i}}{S_{t}{ }^{2}}\right) \\
\text { dengan } \\
s_{t}^{s}=\frac{\sum X_{t}^{2}-\frac{\left(\sum X_{t}\right)^{2}}{N}}{N}
\end{array}
$$

Keterangan:

$r 11=$ Reliabilitas instrumen secara keseluruhan

$\mathrm{p} \quad=$ Proporsi subjek yang menjawab item dengan benar

$\mathrm{q} \quad=$ Proporsi subjek yang menjawab item dengan salah $(q=1-p)$

$\Sigma p q=$ Jumlah hasil perkalian antara $p$ dan $q$

$\mathrm{n}$ = Banyaknya item

$\mathrm{S}=$ Standar deviasi dari tes

Harga $r_{11}$ yang diperoleh kemudian dikonsultasikan dengan harga $r$ pada kriteria reliabilitas soal di bawah ini.

Tabel. Kriteria Reliabilitas Soal

\begin{tabular}{|l|l|}
\hline Harga $\mathbf{r}$ & Keterangan \\
\hline $0,00-0,20$ & Sangat rendah \\
\hline $0,21-0,40$ & Rendah \\
\hline
\end{tabular}




\begin{tabular}{|l|l|}
\hline $0,41-0,60$ & Sedang \\
\hline $0,61-0,80$ & Tinggi \\
\hline $0,81-1,00$ & Sangat tinggi \\
\hline
\end{tabular}

\section{c. Taraf Kesukaran Soal}

Soal yang baik adalah soal yang tidak terlalu mudah atau tidak terlalu sukar. Soal yang terlalu mudah tidak mendorong peserta didik untuk berusaha semaksimal mungkin memecahkan atau memanfaatkan kemampuannya dengan maksimal. Sebaliknya soal terlalu sukar akan membuat peserta didik menjadi putus asa dan tidak bersemangat untuk mencoba lagi karena diluar jangkauannya. Taraf kesukaran diartikan sebagai proporsi siswa peserta didik yang menjawab dengan benar. Pernyataan di atas dinyatakan dalam persamaan sebagai berikut:

$\mathrm{TK}=\frac{\sum \mathrm{B}}{\sum \mathrm{P}}(3.4)$

Keterangan :

TK $=$ Tingkat kesukaran soal

$\sum \mathrm{B}=$ Jumlah siswa yang menjawab soal dengan benar

$\sum \mathrm{p}=$ Jumlah seluruh siswa peserta tes

Menurut ketentuan yang sering diikuti, indeks kesukaran sering diklafiksi sebagai berikut (Purwanto dalam Ratna, 2009;101)

Table. Klafikasi Tingkat Kesukaran

\begin{tabular}{|c|c|}
\hline $\begin{array}{l}\text { Rentang } \\
\text { tingkat } \\
\text { kesukaran }\end{array}$ & Kategori \\
\hline $0,00-0,32$ & Sukar \\
\hline$, 33-0,66$ & Sedang \\
\hline $0,67-1,00$ & Mudah \\
\hline
\end{tabular}

\section{d. Uji Daya Beda}

Daya pembeda soal, adalah kemampuan sesuatu soal untuk membedakan antar siswa yang pandai (berkemampuan tinggi) dengan siswa yang bodoh (berkemampuan rendah). Uji daya beda dimaksudkan untuk menyisihkan butir tes yang mempunyai daya beda rendah. Rumus yang digunakan adalah (Arikunto, 2009: 213-214 )

$$
D=\frac{B_{A}}{J_{A}}-\frac{B_{B}}{J_{B}} \text { (3.5) }
$$

Keterangan :

$J \quad$ : Jumlah peserta tes

JA : Banyak peserta kelompok atas

JB : Banyak peserta kelompok bawah

BA : Banyak peserta kelompok atas yang menjawab soal itu

BB :Banyaknya peserta kelompok bawah yang menjawab soal itu dengan benar
PA : Proporsi peserta kelompok atas yang menjawab benar

PB : Proporsi pesertta kelompok atas yang menjawab benar

Harga yang diperoleh kemudian dikonsultasikan dengan harga $D$ pada kriteria daya pembeda soal di bawah ini.

Tabel Kriteria Daya Pembeda

\begin{tabular}{|c|c|}
\hline Harga D & Keterangan \\
\hline $0,00-0,02$ & Jelek \\
\hline $0,20-0,40$ & Cukup \\
\hline $0,40-0,70$ & Baik \\
\hline $0,70-1,00$ & Baik sekali \\
\hline
\end{tabular}

\section{Teknik Analisis Data}

1. Teknik Analisis Data Hasil Belajar Siswa

Analisis data dilakukan setelah proses pengumpulan data, dimana penelitian ini lebih menitik beratkan pada pengaruh alat peraga fisika berbantukan media buletin fisika berupa buku saku untuk peningkatan hasil belajar siswa kelas MAN 2 Bima. Angket yang digunakan harus dilakukan uji normalitas dan uji homogenitas.

\section{a. Uji Normalitas}

Uji normalitas dilakukan untuk mengetahui data berdistribusi normal atau tidak sehingga langkah selanjutnya tidak menyimpang dari kebenaran dan dapat dipertanggung jawabkan. Data yang akan diuji normalitasnya pada penelitian ini adalah nilai hasil belajar kognitif siswa fisika kelas $\mathrm{X}$ semester I dengan menggunakan uji chikuadrat yaitu:

$$
x^{2}=\sum_{i=1}^{k} \frac{\left(f_{O}-f_{h}\right)^{2}}{f h}
$$

Keterangan:

$\mathrm{X}^{2}=$ chi kudrat

$F_{0}=$ frekuensi yang diobservasi

$\mathrm{f}_{\mathrm{h}}=$ frekuensi yang diharapkan

Kriteria : Jika $X^{2}$ hitung $\leq X^{2}$ tabel dengan $\mathrm{dk}=\mathrm{k}-3$ dan $\alpha=5 \%$ maka data berdistribusi normal.

\section{b. Uji Homogenitas}

Untuk menentukan rumus $t$-test akan dipilih untuk pengujian hipotesis, maka perlu diuji lebih dulu varians kedua sampel homogen atau tidak homogen. Pengujian homogenitas varians digunakan uji $\mathrm{F}$ dengan rumus berikut:

$\mathrm{F}=\frac{\text { Varians terbesar }}{\text { Varians terkecil }}(3.7)$

Kriteria pengujian: Jika

$F_{\text {hitung }}>F_{\text {tabelberarti tidak homogen dan jika }}$ $F_{\text {hitung }}<F_{\text {tabel }}$ berarti homogen pada taraf signifikan 5\% (Sugiyono 2012:199). 


\section{c. Uji Hipotesis (Uji-t)}

Sebelum menguji hipotesis kompratif dua variabel yang berkorelasi maka terlebih dahulu melakukan analisis tentang hubungan antara kedua sampel dengan menggunakan korelasi produk moment yaitu

$$
r_{x y}=\frac{\sum x y}{\sqrt{\left(\sum x^{2}\right)\left(\sum y^{2}\right)}}
$$

Untuk membuktikan signifikan perbedaan hasil belajar siswa sebelum dan sesudah menerapkan media pembelajaran siswa sebelum dan sesudah menerapkan model pembelajaran kooperatif tipe penyelidikan kelompok untuk meningkatkan hasil belajar siswa, perlu diuji secara statistik dengan t-test berkorelasi (related). Untuk menghitung (Uji-t) menggunakan rumus berpasangan/related adalah sebagai berikut :

$$
t=\frac{\overline{\mathrm{X}_{1}}-\overline{X_{2}}}{\sqrt{\frac{s_{1}^{2}}{n_{1}}+\frac{s_{2}^{2}}{n_{2}}-2 r\left(\frac{s_{1}}{\sqrt{n_{1}}}\right)\left(\frac{s_{2}}{\sqrt{n_{2}}}\right)}}
$$

Keterangan:

$t=$ nilai $\mathrm{t}$ yang dihitung

$\overline{\mathrm{X}_{1}}=$ nilai rata-rata kelas eksperimen

$\overline{\mathrm{X}_{2}}=$ nilai rata-rata kelas kontrol

$n_{1} \quad=$ jumlah anggota kelas eksperimen

$n_{2} \quad$ = jumlah anggota kelas kontrol

$s_{1}^{2} \quad=$ varians kelas eksperimen

$s_{2}^{2}=$ varians kelas kontrol

$r \quad=$ korelasi antara data dua kelompok.

Dengan ketentuan jika thitung $>$ tabel maka hipotesis Ha diterima dan Ho ditolak dan thitung<tabel maka hipotesis nol (Ho) dan ( Ha) ditolak (Sugiyono, 2012:274).

\section{Pembahasan}

Secara umum, hasil penelitian ini telah membuktikan hipotesis yang diajukan, yaitu terdapat pengaruh yang signifikan hasil belajar Fisika siswa antara siswa yang belajar dengan menggunakan buletin fisika berbentuk buku saku dan siswa yang menggunakan metode pembelajaran konvensional. Sebelum melakukan uji hipotesis terlebih dahulu melakukan uji analisis data yaitu terlebih dahulu melakukan uji normalitas data hasil belajar kelas eksperimen dilakukan dengan caramembandingkan hasil $\chi^{2}$ hitung dengan $\chi^{2}$ table pada taraf signifikan $5 \%$. Maka distribusi data kelas eksperimen dan kelas kontrol dapat dinyatakan terdistribusi normal.Dengan demikian kedua kelas dapat dinyatakan terdistribusi normal.

Untuk uji homogenitas berdasarkan hasil perhitungan uji homogenitas pada kedua kelas diperoleh bahwa nilai kelas eksperimen dan kelas kontrol dapat dikatakan homogenJadi berdasarkan kriteria yang ada, jika $\mathrm{F}_{\text {hitung }}<\mathrm{F}_{\text {tabel }}$ maka kedua kelas dapat dikatakan memiliki varians yang sama, yang menandakan kedua kelas homogen pada taraf signifikan $5 \%$.

Sesuai hasil penelitian yang diperoleh dari analisis data dan pengujian hipotesis yang telah menunjukkan bahwa "ada pengaruh buletin fisika berbentuk buku saku terhadap peningkatkan hasil belajar siswa kelas X MAN 2 Bima pada materi hukum newton tahun pelajaran 2018/2019. Perbedaan yang signifikan ini terlihat dari analisis uji hipotesis yang telah dilakukan dengan menggunakan uji-t. Hasil analisis menunjukkan bahwa hasil uji t diperoleh thitung $=3,630$. Hasil uji $t$ tersebut kemudian dikonsultasikan pada trabel. dengan taraf signifikan $5 \%$ dan $\mathrm{db}=54$ diperoleh tabel $=2,175$, karena thitung $\geq$ tabel, maka Hipotesis $\mathrm{Ha}$ diterima, dengan demikian ada pengaruh buletin fisika berbentuk buku saku terhadap peningkatkan hasil belajar siswa kelas X MAN 2 Bima pada materi hukum newton tahun pelajaran 2018/2019.

Hasil observasi proses belajar siswa selama proses pembelajaran berlangsung dapat dilihat bahwa ada perbedaan proses belajar siswa dengan Penerapan Buletin fisika berbentuk buku saku dengan menggunakan metode ceramah. Data hasil observasi kegiatan belajar siswa, memperlihatkan bahwa penyampaian tujuan dan memotivasi, aktivitas pembelajaran serta tanggapan terhadap pemberian penghargaan dengan kategori baik. Sementara itu, kegiatan belajar siswa dalam memperhatikan penyampaian materi, keseriusan dan kesungguhan mengerjakan tes dengan kategori sangat baik. Kegaiatan mengajar guru dalam menyampaikan tujuan dan memotivasi serta membimbing siswa dikategorikan baik dan kegiatan mengajar guru dalam menyajikan informasi, memperhatikan proses belajar siswa, melakukan evaluasi dan memberikan penghargaan dikategorikan sangat baik.

Peningkatan yang diperoleh dari hasil kegiatan belajar mengajar disebabkan oleh beberapa hal antara lain siswa telah terbiasa dalam proses belajar mengajar yang menggunakan strategi pemecahan masalah sehingga ada perasaan tertarik dan sungguhsungguh dalam mengikuti proses belajar 
mengajar. Begitu juga pada proses diskusi atau tanya jawab terjadi komunikasi yang baik antara guru dan siswa tentang materi yang disampaikan. Hal ini berpengaruh terhadap hasil ketuntasan yang diperoleh siswa.

Berdasarkan data hasil observasi kegiatan belajar mengajar dengan penerapan Buletin fisika berbentuk buku saku mununjukkan bahwa siswa mengalami suatu bentuk perubahan yang baru secara keseluruhan sebagai hasil pengalamannya sendiri dalam interaksi dengan lingkungannya.

Berdasarkan hasil penelitian bahwa, ada perbedaan yang signifikan antara kelas eksperimen dengan kelas kontrol. Hal ini terlihat pada kelas eksperimen tampak bahwa siswa kreatif dan memahami apa yang dijelaskan oleh guru dan siswa lebih siap mengerjakan soal latihan yang diberikan oleh guru. Sedangkan pada kelas kontrol siswa fakum dan banyak diam. Dalam proses belajar mengajar, metode mengajar merupakan hal yang terpenting, sebab metode mengajar merupakan faktor penunjang dalam menyampaikan materi pelajaran yang akan mampu meningkatkan Hasil Belajar. Setiap metode mengajar mempunyai kelemahan dan kelebihan serta daya cocok yang berbeda bagi setiap siswa. Oleh karena itu, kemampuan guru dalam memiliki metode yang sesuai dengan materi pelajaran dan kondisi fisik siswa akan sangat mempengaruhi Hasil Belajar siswa.

Kondisi emosional ataupun minat merupakan salah satu kondisi psikologis yang mempengaruhi Hasil Belajar siswa (Slameto: 2003: 32). Rasa senang pada saat belajar sambil bermain menggambarkan kondisi emosi yang dapat meningkatkan motivasi anak untuk lebih aktif belajar sehingga pembelajaran Fisika lebih berhasil. Seperti halnya yang telah diungkapkan bahwa pengajaran Fisika lebih berhasil apabila menggunakan penerapan Buletin fisika berbentuk buku saku dari pada diberi ceramah atau diskusi.

Penerapan Buletin fisika berbentuk buku saku memberikan peluang yang lebih besar untuk peningkatan Hasil Belajar Fisika siswa khususnya pada pada materi Hukum newton. Sebab dengan penerapan Buletin fisika berbentuk buku saku, peserta didik akan dapat memiliki keterampilan dalam menyelesaikan permasalahan yang memuat tentang Hukum newton. Hal ini sesuai dengan ungkapan (Isjoni 2007: 49) bahwa penerapan Buletin fisika berbentuk buku saku, siswa akan memiliki pengalaman belajar yang berbeda dan bervariasi mengenai suatu konsep atau topik dalam suasana yang menyenangkan sehingga lebih merangsang minat peserta didik untuk belajar sehingga siswa akan lebih termotivasi dalam belajarnya.

Berbeda dengan model pembelejaran konvensioanal yang dimana siswa hanya membaca, menulis, dan mendengarkan. Sehingga kegiatan belajar siswa hanya terpacu pada mebaca, menulis, dan mendengarkan saja. Kegiatan proses belajar mengajar lebih berpusat pada guru dan pada buku pegangan siswa sehingga komunikasi satu arah dari guru kepada siswa kurang. sedang siswa hanya membaca, menulis, dan mendengarkan apa yang disampaikan guru sehingga cenderung meminimalkan keterlibatan siswa serta guru nampak lebih aktif atau dan belum menerapkan model pembelajaran yang inovatif.

Paparan tersebut menjadi alasan pendukung bahwa Buletin fisika berbentuk buku saku, memang logis lebih berpengaruh baik terhadap hasil belajar dibandingkan dengan model pembelajaran konvensioanal yang hanya menstransfer pengetahuan tanpa memperhatikan potensi siswa.

\section{SIMPULAN DAN SARAN Simpulan}

Hasil penelitian dan pembahasan yang telah diungkapkan pada bagian sebelumnya, maka dapat diambil kesimpulan bahwa terdapat pengaruh yang signifikan hasil belajar Fisika siswa kelas eksperimen dengan menggunakan Buletin fisika berbentuk buku saku dengan kelas kontrol yang menggunakan model pembelajaran konvensioanal pada siswa kelas X di MAN 2 Bima Tahun Pelajaran 2018/2019. Hal ini bisa dilihat dari nilai rata-rata kelas kelas eksperimenpre test yaitu 61 dan post test yaitu 82, sedangkan kelas kontrol hasil belajar nilai rata-rata pre test yaitu 61 dan post test yaitu73.

Berdasarkan hasil perhitungan uji hipotesis dengan menggunkan rumus uji-tes, maka diperoleh $t_{\text {hitung }}$ sebesar 3,630 sedangkan nilai $t_{\text {tabel }}$ pada taraf signifikan $5 \%$ dengan $\mathrm{dk}=$ $n_{1}+n_{2}-2=28+28-2=54$ diperoleh harga $t_{\text {tabel }}$ sebesar 2,175. Jadi dari hasil perhitungan dapat disimpulkan $t_{\text {hitung }}>t_{\text {tabel }}$, maka dapat dikatakan hipotesis $(\mathrm{Ha})$ diterima. ini berarti bahwa "ada pengaruh buletin fisika berbentuk buku saku terhadap peningkatkan hasil belajar siswa kelas X MAN 2 Bima pada materi hukum newton tahun pelajaran 2018/2019".

\section{Saran}

Berdasarkan kesimpulan di atas, maka dapat disarakan sebagai berikut:

1. Bagi siswa, hasil penelitian ini dapat meningkatkan hasil belajar siswa dalam mempelajari mata pelajaran fisika.

2. Bagi Guru, sebagai rujukan bagi guru yang ingin menenerapkan pembelajaran yang tepat dalam proses belajar mengajar dalam pendidikan fisika.

3. Bagi Sekolah, hasil penelitian ini dapat 
memberikan konstribusi yang baik dalam rangka perbaikan pembelajaran di sekolah khususnya pembelajaran pendidikan fisika. Selain itu, sekolah dapat memberikan rekomendasi kepada guru lain untuk menerapkan pembelajaran pendidikan.

\section{DAFTAR RUJUKAN}

Arikunto. 2010. Prosedur Penelitian Suatu Pendekatan Praktik. Jakarta: Rineka Cipta

Arsyad, Azhar. 2014. Media Pembelajaran Edisi Revisi. Jakarta: Rajawali Pers

Djamarah, Syaiful Bahri dan Aswan Zain. 2006. Strategi Belajar Mengajar. Jakarta: PT. Rineka Cipta

Fatimah, Siti. 2013. Pembelajaran Fisika Menggunakan Modul Dan Buletin Berbasis Masalah Ditinjau Dari Motivasi Belajar Siswa: Universitas Sebelas Maret, Vol. 4 No. 1 ISSN: 2087-0922. Diakses pada tanggal 24 September 2015

Hake, R.R. (1998). Interactive-engagement versustraditional methods: $A$ sixthousand-student survey of mechanics test data for introductory physics courses.American Journal of Physics 66, 64 (1998). 10.1119/1.18809

Hamalik, Oemar. 2001.Proses Belajar Mengajari. Jakarta: PT. Bumi Aksara

Hartati.2010. Pengembangan Alat Praga Gaya Gesek Untuk Meningkatkan Keterampilan Berpikir Kritis Siswa SMA.Jurnal Pendidikan Fisika Indonesia 6. ISSN: 1693-1246. Diakses pada tanggal 24 September 2015

Islahudin, I., Darmayanti, N.W.S., Zulkarnain, Z, (2017). Pengaruh Pemanfaatan Alat Peraga Berbasis Kearifan Lokal Terhadap Peningkatan Hasil Belajar Fisika Pada Siswa Kelas VIII Di MTs Nurul Iman NW Kembang Kerang Lombok Tengah Tahun Pelajaran 2017/2018.. ORBITA : Jurnal Kajian, Inovasi dan Aplikasi Pendidikan Fisika. 3(2), 46-52.

Jannah, Zulfa B., Islahudin, I., Darmayanti, N.W.S, (2018). Pengembangan Modul Fisika Bilingual Materi Hukum Newton Pada Siswa SMA Kelas X Untuk Meningkatkan Motivasi Belajar Fisika Tahun Ajaran 2017/2018.. ORBITA : Jurnal Kajian, Inovasi dan Aplikasi Pendidikan Fisika. 4(2), 37-46.

Julaiha, J., Islahudin, I., Sabaryati, J, Pengaruh Penggunaan Alat Peraga Berbantukan Kearifan Lokal Terhadap Hasil Belajar Siswa Kelas VII Di MTs Negeri 3
Mataram, ORBITA : Jurnal Kajian, Inovasi dan Aplikasi Pendidikan Fisika. 3(2), 1-7.

Kustandi, Cecep dan Bambang Sutjipto. 2011. Media Pembelajaran Manual dan Digital Edisi Kedua. Ghalia Indonesia: Jakarta

Putri, Nur Rizki, dkk. 2015. Pengembangan Buletin Pembelajaran Fisika Pokok Bahasan Gerak Melingkar Pada Siswa Kelas X IPA SMA Negeri 3 Purwerejo Tahun Pelajaran 2014/2015: Universitas Muhammadiyah Purworejo, Vol. 6 No.1. Diakses pada tanggal 2 November 2015.

Purwanto. 2010. Evaluasi hasil belajar. Jogyakarta: pustaka pelajar.

Riduwan. 2014. Metode dan Teknik Menyusun Proposal Penelitian. Bandung: Alfabeta

Ramadhan, Nur., Utami, L.S., \& Sabaryati, J, (2017). Pengembangan Media Pembelajaran Posbuk (Poster Buku) Untuk Meningkatkan Pemahaman Konsep Siswa Kelas X Pada Materi Hukum Newton, ORBITA : Jurnal Kajian, Inovasi dan Aplikasi Pendidikan Fisika. 3(2), 820.

Ropita, D. 2015.Pengembangan Buletin Fisika Berbentuk Buku Saku UntukMeningkatkan Motivasi Belajar Siswa Sma Model Nurul Jannah Kelas $X$ Materi Suhu Dan Kalor Tahun Pelajaran 2015/2016. UMMAT.Skripsi: Tidak di Publikasikan

Setyono, Yulian Adi., dkk. 2013. Pengembangan Media Pembelajaran Fisika Berupa Buletin dalam Bentuk Buku Untuk Pembelajaran Fisika Kelas VII Materi Gaya Ditinjau Dari Minat Baca Siswa: Universitas Sebelas Maret, Vol.1 No.1 ISSN: 2338-0691. Diakses pada tanggal 20 November 2015

Sugiyono. 2013. Metode Penelitian Kuantitatif Kualitatif dan $R$ \& $D$. Bandung: AlfabetaYoung dan Freednan. 2001. Fisika Universitas Edisi Kesepuluh Jilid I. Jakarta: Erlangga.

Wahyu, Dian Y., Islahudin, I., Zulkarnain, Z, (2018). Analisis Kemampuan Mahasiswa Menentukan Persamaan Hukum Newton Di Program Studi Pendididkan Fisika Universitas Muhammadiyah Mataram Tahun 2017. ORBITA : Jurnal Kajian, Inovasi dan Aplikasi Pendidikan Fisika. 4(1), 28-37. 